\title{
Is Transition to E-Learning Effective amongst Dental Students during Covid-19 Era??
}

\section{Urvi Shah, Dhwani Ranveria*, Hiren Patel, Haren Pandya, Hitesh Dewan and Bijal Bhavsar}

\author{
Department of Oral and Maxillofacial Surgery, Faculty of Dental Sciences, \\ Dharmasinh Desai University, Nadiad, Gujarat, India
}

*Corresponding Author: Dhwani Ranveria, Lecturer, Department of Oral and Maxillofacial Surgery, Faculty of Dental Sciences, Dharmasinh Desai University, Nadiad, Gujarat, India.
Received: June 26, 2021

Published: July 28, 2021

(C) All rights are reserved by Dhwani

Ranveria., et al.

\begin{abstract}
Background: Dental education has more or less relied upon traditional classroom teaching where a face to face interaction exists amongst educators and students. However, emergence of worldwide pandemic due to covid-19 as declared by WHO in January 2020 has necessitated the need of social distancing. Consequently, all the education institutes have faced a dire situation of conducting the studies online via virtual classrooms, dentistry being no exemption.

Material and Method: To analyze the impact of e learning among dental students a survey was carried out amongst undergraduate students of various dental colleges. Structured questionnaire was prepared in Google form including 15 questions and circulated amongst them. The collected data was tabulated using Microsoft excel. After that relevant Chi-square test was performed and the results were analyzed. Some results are shown in absolute percentages.

Results: In our study 78.4\% dental students found virtual classrooms helpful for study during this covid-19 era.

Conclusion: Practical knowledge is utmost important in dentistry though when everything was shut down and social distancing was of great necessity for the sake of survival of individuals virtual classrooms were found helpful. Well-structured implementation of virtual study is essential to be incorporated in dental curriculum for better synchronous format that is formulated keeping the best interest of students in mind.
\end{abstract}

Keywords: Transition; E-Learning; Dental Students; Covid-19

\section{Introduction}

Commensurate with the advances in digital world, Pedagogical spectrum in dentistry has been implementing digital tools within its armamentarium depending upon their efficacy and availability. These applications range from web based knowledge transfer to using practical oriented trainings in terms of using digital radiography, use of 3D models, CAD-CAM based impression taking and so on. That being said, traditional classroom teaching is still the preferred mode of education delivery across the dental institutes in India, with little inclination to shift towards an online format [1].

However, the global crisis due to Covid 19 pandemic in 2020 (as declared by WHO) posed an unprecedented challenge to the edu- cation sector as it led to a shutdown of the campuses thus severing the physical connect between the faculty and students [2].

As per DCI advisory issued on $16^{\text {th }}$ April 2020 all the professional educational institutes were asked to close completely or suspend classes and offer e-learning and work from home, maintain social distancing. The educators were instructed to continue dental education using various digital platforms as per availability [3].

Aiming to cope with this emergency, the dental institutes saw a sudden shift from traditional classroom learning to computer-based learning which might be one of the largest educational experiments to date [2]. 
The present study was therefore designed to gain feedback of dental students in regards to their experience with online sessions, their preference for platform. We also inquired about potential health related issues owing to e learning in order to incorporate a more holistic approach in preparing a future curriculum for dentistry.

\section{Materials and Methods}

A 15-question anonymous survey was created and distributed electronically to $1^{\text {st }}, 2^{\text {nd }}, 3^{\text {rd }}$ and final year undergraduate dental students across the state of Gujarat. The participation wasvoluntary.

A questionnaire was designed after a pilot discussion with undergraduate dental students. The survey was developed to interpret students' perceptions of the web-based learning and its effects on their academic performance. Dental students studying in dental institutions across the Gujarat state in undergraduate program were selected randomly with the identity to be kept anonymous.

\section{Exclusion criteria:}

1. Students involved in pilot studying group.

2. Incomplete survey.

3. Those who did not consent to the survey.

4. Teachers

A total of 619 responses were gathered.

The collected data was tabulated using Microsoft excel. The raw data which was obtained through the survey were analyzed. After that relevant Chi-square test was performed and the results were analyzed. Some results are shown in absolute percentages.

\section{Results}

During the study period, a total of 619 dental students participated in the study. Out of which $78.4 \%$ students said that virtual classroom studies were helpful during COVID-19.

$61.7 \%$ students have said that they would like to attend real classroom more during routine schedule but they also said that virtual classroom studies helped them during covid-19.

Mobiles and laptops both are preferred gadgets for virtual classroom study (43.5\%).

If we use technology in correct way it will help us in learning but sometimes students missuses the technology. 14.5\% students said that they sometimes get logged in themselves for attendance instead of actually attending virtual classroom study. $35.9 \%$ students said that they do the same sometimes.
$55.6 \%$ students said that virtual classroom study is a good way to develop self-learning ability.

Lot of material available on internet so sometimes students feel distracted (65.1\%).

\section{Advantages}

Most cited advantage of virtual classroom study is, if recorded multiple revisions can be done (71.8\%). Second most cited advantage is distance learning is possible $(59.90 \%)$.

\section{Disadvantages}

Most cited disadvantage is internet connection issue (74.20\%). Second most cited disadvantage is lack of practical knowledge (68.30\%).

\section{VIRTUAL CLASSROOM HELPFUL DURING COVID 19??}
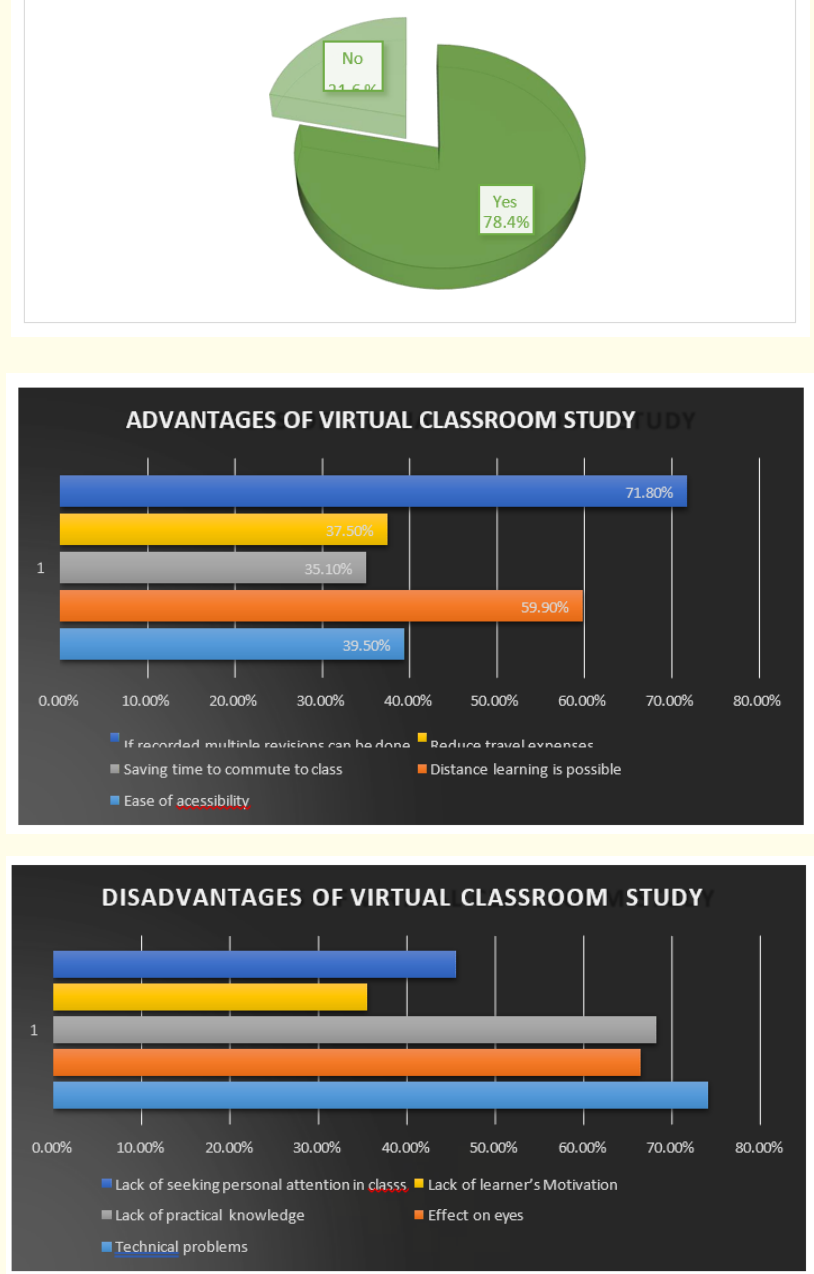

Figure 1 
For following We have done chi-square test for following to obtain results.

Null hypothesis 1: There is no association between attending virtual classes and successfully able to create study atmosphere through virtual class at home.

Alternative hypothesis 1: There is strong association between attending virtual classes and successfully able to create study atmosphere through virtual class at home.

\section{Test output}

\begin{tabular}{|c|c|c|c|}
\hline \multicolumn{4}{|c|}{$\begin{array}{l}\text { Attending_virtual_class } * \text { Are_you_able_to_create_study_ } \\
\text { atmosphere_at_home Crosstabulation }\end{array}$} \\
\hline & \multicolumn{2}{|c|}{$\begin{array}{c}\text { Are you able } \\
\text { to create study } \\
\text { atmosphere at } \\
\text { home }\end{array}$} & \multirow[t]{2}{*}{ Total } \\
\hline & Yes & No & \\
\hline \multirow{2}{*}{ Attending_virtual_class $\frac{\mathrm{Ye}}{\mathrm{Nc}}$} & 280 & 220 & 500 \\
\hline & 63 & 55 & 118 \\
\hline Total & 283 & 335 & 618 \\
\hline
\end{tabular}

\begin{tabular}{|c|c|c|c|c|c|}
\hline \multicolumn{6}{|c|}{ Chi-Square Tests } \\
\hline & Value & df & \begin{tabular}{|} 
Asymp. \\
Sig. \\
(2-sided)
\end{tabular} & $\begin{array}{l}\text { Exact Sig. } \\
\text { (2-sided) }\end{array}$ & Exact Sig. \\
\hline Pearson Chi-Square & $3.391^{\mathrm{a}}$ & 1 & .066 & & \\
\hline Continuity Correction ${ }^{\mathrm{b}}$ & 3.023 & 1 & .082 & & \\
\hline Likelihood Ratio & 3.380 & 1 & .066 & & \\
\hline Fisher's Exact Test & & & & .081 & .041 \\
\hline $\begin{array}{l}\text { Linear-by-Linear As- } \\
\text { sociation }\end{array}$ & 3.385 & 1 & .066 & & \\
\hline $\mathrm{N}$ of Valid Cases ${ }^{\mathrm{b}}$ & 618 & & & & \\
\hline \multicolumn{6}{|c|}{$\begin{array}{l}\text { a. } 0 \text { cells }(.0 \%) \text { have expected count less than } 5 \text {. The minimum expected } \\
\text { count is } 54.04 \text {. }\end{array}$} \\
\hline b. Computed only for a & 2 table & & & & \\
\hline
\end{tabular}

Table 1

\section{Test interpretation}

We can see that the chi-square value calculated come out to be 0.041 which is less than 0.05 [test criteria] hence we reject the null hypothesis and accept the alternative hypothesis. In other words, there is strong association between attending virtual classes and successfully able to create study atmosphere through virtual class at home. It is hence proved from the cross tabulation table that out of 500 students attending virtual classes from home, 280 of them cited that they were success in creating study atmosphere through virtual classroom at home.

Null hypothesis 2: There is no association between preference to attend virtual classroom and thinking that virtual classrooms are a better way to develop self learning ability.

Alternative hypothesis 2: There is strong association between preference to attend virtual classroom and thinking that virtual classrooms are a better way to develop self learning ability.

Test output

\begin{tabular}{|l|c|c|c|c|}
\hline \multicolumn{3}{|c|}{$\begin{array}{r}\text { what_do_you_prefer_to_Attend * is_VC_a_better_way_to_ } \\
\text { develop_self- learning_abiltiy Crosstabulation }\end{array}$} \\
\hline \multicolumn{4}{|c|}{} & \multicolumn{2}{|c|}{$\begin{array}{r}\text { is_VC_a_better_way_to_ } \\
\text { develop_l learning_abiltiy }\end{array}$} & \multirow{2}{*}{ Total } \\
\cline { 2 - 5 } & Yes & No & 381 \\
\hline \multirow{2}{*}{$\begin{array}{l}\text { what_do_ } \\
\text { you_prefer_ } \\
\text { to_Attend }\end{array}$} & Yes & 216 & 165 & 139 \\
\cline { 2 - 5 } & No & 108 & 31 & 99 \\
\hline Total & Sometimes & 71 & 28 & 619 \\
\hline
\end{tabular}

\begin{tabular}{|l|c|c|c|}
\hline \multicolumn{4}{|c|}{ Chi-Square Tests } \\
\hline & Value & df & $\begin{array}{c}\text { Asymp. Sig. } \\
\text { (2-sided) }\end{array}$ \\
\hline Pearson Chi-Square & $61.228^{\mathrm{a}}$ & 2 & .001 \\
\hline Likelihood Ratio & 63.612 & 2 & .000 \\
\hline Linear-by-Linear Association & 45.248 & 1 & .000 \\
\hline N of Valid Cases & 619 & & \\
\hline $\begin{array}{l}\text { a. } 0 \text { cells (.0\%) have expected count less than 5. The minimum } \\
\text { expected count is 43.98. }\end{array}$ \\
\hline
\end{tabular}

Table 2

\section{Test interpretation}

We can see that the chi-square value calculated come out to be 0.001 which is less than 0.05 [test criteria] hence we reject the null hypothesis and accept the alternative hypothesis. In other words, there is strong association between preference to attend virtual classroom and thinking that virtual classrooms are a better way to develop self learning ability. It can be hence proved from the cross tabulation table that out of 381 students attending virtual classes, 216 cited that attending virtual classroom are a better way to develop self-learning ability.

Null hypothesis 3: There is no association between preference to attend virtual classroom and ability to maintain the same level of concentration as in physical classroom 
Alternative hypothesis 3: There is strong association between preference to attend virtual classroom and ability to maintain the same level of concentration as in physical classroom.

Test output

\begin{tabular}{|c|c|c|c|c|}
\hline \multicolumn{5}{|c|}{$\begin{array}{c}\text { Preference_to_attend }{ }^{*} \text { able_to_maintain_same_level_of_con- } \\
\text { centration Crosstabulation }\end{array}$} \\
\hline \multicolumn{5}{|l|}{ Count } \\
\hline & & \multicolumn{2}{|c|}{$\begin{array}{l}\text { able_to_maintain_- } \\
\text { same_level_of_concen- } \\
\text { tration }\end{array}$} & \multirow{2}{*}{ Total } \\
\hline & & Yes & No & \\
\hline \multirow{3}{*}{$\begin{array}{l}\text { Preference_- } \\
\text { to_attend }\end{array}$} & Yes & 63 & 318 & 381 \\
\hline & No & 86 & 53 & 139 \\
\hline & Sometimes & 60 & 39 & 99 \\
\hline \multicolumn{2}{|l|}{ Total } & 209 & 410 & 619 \\
\hline
\end{tabular}

\begin{tabular}{|l|c|c|c|}
\hline \multicolumn{4}{|c|}{ Chi-Square Tests } \\
\hline & Value & df & $\begin{array}{c}\text { Asymp. Sig. } \\
\text { (2-sided) }\end{array}$ \\
\hline Pearson Chi-Square & $1.316 \mathrm{E} 2^{\text {a }}$ & 2 & .002 \\
\hline Likelihood Ratio & 132.397 & 2 & .000 \\
\hline $\begin{array}{l}\text { Linear-by-Linear } \\
\text { Association }\end{array}$ & 107.992 & 1 & .000 \\
\hline N of Valid Cases & 619 & & \\
\hline
\end{tabular}

a. 0 cells $(.0 \%)$ have expected count less than 5 . The minimum expected count is 33.43 .

Table 3

\section{Test interpretation}

We can see that the chi-square value calculated come out to be 0.002 which is less than 0.05 [test criteria] hence we reject the null hypothesis and accept the alternative hypothesis. In other words, there is strong association between attending virtual classrooms and ability to maintain the same level of concentration as in physical classroom. It is hence proved by the cross tabulation table that out of 381 who preferred to attend virtual classroom, 318 cited that they were not able togenerate the ability to maintain the same level of concentration as in a physical classroom.

Null hypothesis 4: There is no association between preference to attend virtual classroom and acquire same knowledge as in traditional classroom.

Alternative hypothesis 4: There is strong association between preference to attend virtual classroom and acquire same knowledge as in traditional classroom.
Test output

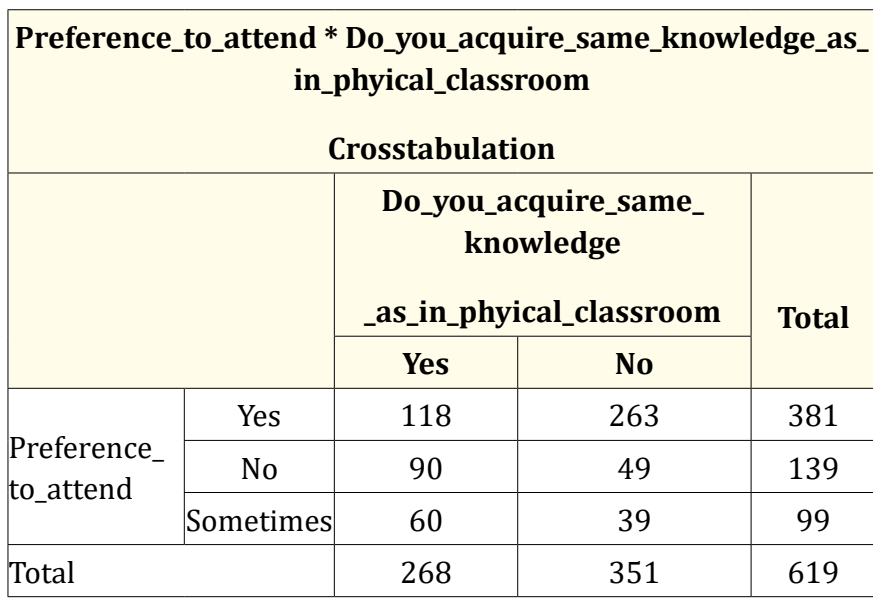

\begin{tabular}{|c|c|c|c|}
\hline \multicolumn{4}{|c|}{ Chi-Square Tests } \\
\hline & Value & df & $\begin{array}{l}\text { Asymp. Sig. } \\
\text { (2-sided) }\end{array}$ \\
\hline Pearson Chi-Square & $61.712^{\mathrm{a}}$ & 2 & .001 \\
\hline Likelihood Ratio & 62.201 & 2 & .000 \\
\hline $\begin{array}{l}\text { Linear-by-Linear } \\
\text { Association }\end{array}$ & 47.523 & 1 & .000 \\
\hline $\mathrm{N}$ of Valid Cases & 619 & & \\
\hline \multicolumn{4}{|c|}{$\begin{array}{c}\text { a. } 0 \text { cells }(.0 \%) \text { have expected count less than } 5 \text {. The minimum } \\
\text { expected count is } 42.86 .\end{array}$} \\
\hline
\end{tabular}

Table 4

\section{Test interpretation}

We can see that the chi-square value calculated come out to be 0.001 which is less than 0.05 [test criteria] hence we reject the null hypothesis and accept the alternative hypothesis. In other words, there is strong association between preferences to attend virtual classroom and acquire same knowledge as in traditional classroom.

Hence proved from the cross-tabulation table that out of 381 students who attend virtual classrooms, 263 students cited that they are unable to acquire same knowledge as in traditional classroom.

\section{Discussion}

Digital tools like these have made their presence over past two decades within dental curriculum across the country. This being noted, the web-based learning platform for knowledge transfer or conducting students' assessments is yet to be perceived with a lot of skepticism [4].

Integration of online education in dentistry in India has so far been in its budding stages and hasn't received any significant mo- 
mentum, with traditional classroom teaching still dictating pedagogical approach2. Major factors to be cited for this are: lack of enough literature which showcases the effectiveness of online learning both amongst educators as well as students in dentistry, internet issues, lack of tools essential to teach practical sessions online, reluctance amongst teachers to switch to newer pedagogy platforms [1]. The Covid-19 situation has modified the mode of interaction worldwide, the physical distancing being imposed as the ways to avoid its transmission. This has made a huge impact on university education. How the educational landscape shall be drawn in future is still highly uncertain posing a huge challenge for ongoing teaching especially in a developing country like India.

In this scenario most of educational institutions have been forced to shift their teaching apparatus entirely to one of online delivery overnight, dentistry being no exception. Today online teaching is more of a necessity than an option [5].

This can be viewed as both a challenge as well as an opportunity to explore the potential of e learning format for pedagogy for a better synchronous synthesis within the curriculum, to draw conclusions from data collected from its participants and achieve the desired learning goals after considering its merits and demerits.

Dentistry, as a discipline, is a highly technique sensitive branch, where besides gaining theoretical knowledge, students have to partake in preclinical and clinical training and work on their motor skills under the guidance of faculty. While a face-to-face approach is imperative for practical knowledge transfer, digital software tools can be used to substantiate the learning process by evaluating manual abilities, analyzing their preclinical preparedness, to enable self-assessment and self-correction [1].

Thus, though conventional classroom cannot be completely replaced by online one, the emergency situation owing to covid 19 pandemic has compelled us to quickly adapt and adjust to this alternative mode of delivery, tap all the available resources within realm and make use of them in utmost effective way.

The goal of this survey was to explore student's perceptions in regards to online learning. Factors such as "level of concentration", "classroom atmosphere", "acquiescence of knowledge" "improve self-learning abilities", "general effects on health", "the merits and demerits of e-learning" were given due consideration.

The utmost advantage cited by students for e learning was the facility of revision of recorded video lectures.

Another credible attribute is the allowance of continued education through distant learning. These are followed by ease of accessi- bility and reduced travel time along with the expenses. Study time also becomes flexible without even attending the campus.

Self learning ability promotes the natural development of self-confidence, initiative perseverance and life satisfaction. Through Virtual classrooms students can enhance their self-learning ability.

Amongst the drawbacks of the web-based learning as cited by students, the technical issues in relation to internet was at the forefront. This draws our attention to first strengthen the connectivity network in India at large ensuring uninterrupted access to internet for sound delivery of online classes.

Hence, the educators have to be cognizant with different modes of online education such as the recorded videos, webinars and video conferencing.

Most of students prefer traditional classroom, because in a traditional classroom students can interact with their teachers and colleagues face to face. Traditional classroom education often has a greater availability of advanced training programs with hands-on training which is more important aspect in dental education.

In traditional classrooms no extra effort is needed to create a study environment but in virtual classroom its hard to achieve same study environment as in traditional classroom. Study environment also affects the level of concentration of individual students because of physical presence of educator students can maintain high level of concentration in traditional classroom.

Nowadays lot of study material is available online by using this materials one can acquire good amount of theoretical knowledge even without attending traditional classroom.

This does not say that e-learning could ever replace the traditional pedagogical format the emergency situation like COVID-19 has necessitated the need to quickly adapt and adjust to online teaching, which can be deemed both as a challenge as well an opportunity, to whether it can be integrated in our modus operandi in future.

\section{Hybrid study model}

Covid-19 Pandemic have taught us that "Don't dig well when the house is on fire". We were completely underprepared to cope with such situation though we some how manage to escape from the situation unwounded in educational sector of dentistry.

For better future of dental educational curriculum we hereby propose hybrid study model to create a balanced education system in dentistry field. 
$50 \%$ time duration of lectures per week can be taken as virtual classroom. Basic lecture can be conducted virtually in the form of recorded video or video conference. Following study variables should be kept in mind for conducting virtual classroom. For better virtual classrooms need of infrastructure with internet facility is must.

Study variables for virtual classroom

- Mental health

- Mode of interaction

- Content

- Motivation

- Internet facility.

Attendance can be taken after basic lecture and after that in traditional classroom high end discussions can be carried out (Doubt solving sessions.). Study materials can be provided to students and at last assessment must be carried out to evaluate the efficacy of students.

Study variables for traditional classroom

- High level of interaction

- Study material

- Assessment [6-17].

Hybrid study model

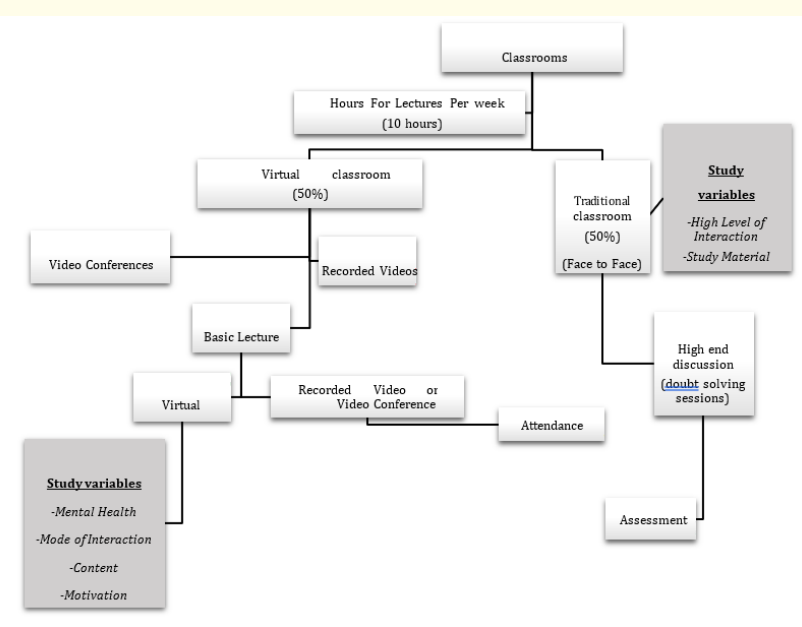

Figure 2

\section{Conclusion}

Though Virtual classrooms can never replace traditional one in a speciality like dentistry, they are an important asset for future edu- cation. The ultimate aim for educational research shall be how to optimize the available resources to maximize the learning opportunities for the students.

Further surveys in regards to both faculty as well as students should be conducted for an in depth analysis of this novel approach to education.

\section{Bibliography}

1. Cook DA., et al. "Internet-Based Learning in the Health Professions A Meta-analysis". The Journal of the American Medical Association 300.10 (2008): 1181-1196.

2. Saha S. "Secretary. Covid-19 guidelines for dental colleges, dental students and dental professionals by dental council of India" (2020): 1-10.

3. Sufeng Y and Runjuan S. "Virtual Classroom and Traditional Classroom". International Conference on Education Technology and Management Science (2013):114-116.

4. Turyilimaz I., et al. "Student's perception of the impact of Elearning on dental education". The Journal of Contemporary Dental Practice 20.5 (2019): 616-621.

5. Murphy M PA. "COVID-19 and emergency eLearning: Consequences of the securitization of higher education for post-pandemic pedagogy". Contemporary Security Policy (2020).

6. Lall S and Singh N. "COVID-19: Unmasking the new face of education". International Journal of Research in Pharmaceutical Sciences 11.1 (2020): 48-53.

7. Martin A. "How to optimize online learning in the age of corona virus (COVID-19): A 5- point guide for educators (2020).

8. Liguori E and Winkler C. "From Offline to Online: Challenges and Opportunities for Entrepreneurship Education Following the COVID-19 Pandemic". Entrepreneurship Education and Pedagogy (2020): 1-6.

9. Pei $\mathrm{L}$ and $\mathrm{Wu} \mathrm{H}$. "Does online learning work better than offline learning in undergraduate medical education? A systematic review and meta-analysis". Medical Education Online 24 (2019): 1666538.

10. Dhawan S. "Online Learning: A Panacea in the Time of COVID-19 Crisis". Journal of Educational Technology Systems (2020): 1-18.

11. Paul J and Jefferson F. "A Comparative Analysis of Student Performance in an Online vs. Face-to-Face Environmental Science 
Course From 2009 to 2016 ,2019". Frontiers of Computer Science 1 (2019): 7.

12. Agarwal S and Kaushik JS. "Student's Perception of Online Learning during COVID Pandemic". The Indian Journal of pediatric 87.7 (2020): 554 .

13. Smart KL and Cappel JJ. “Students' Perceptions of Online Learning: A Comparative Study". Journal of Information Technology Education 5 (2006).

14. Martin F and Noonan D. "Synchronous Technologies for Online Teaching (2010).

15. Posey G., et al. "The Advantages and Disadvantages of the Virtual Classroom and the Role of the Teache". Alabama A and M University.

16. Li F., et al. "Traditional Classroom VS E-learning in Higher Education: Difference between Students' Behavioral Engagement”. International Journal of Emerging Technologies 9.2 (2014).

17. Kemp N and Grieve R. "Face-to-face or face-to-screen? Undergraduates' opinions and test performance in classroom vs. online learning". Frontiers in Psychology 5 (2014): 1278.

\section{Volume 5 Issue 8 August 2021}

(C) All rights are reserved by Dhwani Ranveria., et al. 